\title{
Vehicle driving cycle performance of the spark-less di-ji hydrogen engine
}

\author{
Alberto A. Boretti \\ School of Science and Engineering, University of Ballarat, PO Box663, Ballarat, VIC 3353, Australia
}

\section{A R T I C L E I N F O}

Article history:

Received 29 January 2010

Received in revised form

26 February 2010

Accepted 27 February 2010

Available online $\mathrm{xxx}$

Keywords:

Gas engines

Direct injection

Jet ignition

Glow plug controlled auto ignition

Lean burn stratified combustion

Bulk ignition and combustion

Engine simulations

Vehicle simulations

Driving cycles

\begin{abstract}
A B S T R A C T
The paper describes coupled CFD combustion simulations and CAE engine performance computations to describe the operation over the full range of load and speed of an always lean burn, Direct Injection Jet Ignition (DI-JI) hydrogen engine. Jet ignition pre-chambers and direct injection are enablers of high efficiencies and load control by quantity of fuel injected. Towards the end of the compression stroke, a small quantity of hydrogen is injected within the spark-less pre-chamber of the DI-JI engine, where it mixes with the air entering from the main chamber and auto-ignites because of the high temperature of the hot glow plug. Then, jets of partially combusted hot gases enter the main chamber igniting there in the bulk, over multiple ignition points, lean stratified mixtures of air and fuel. Engine maps of brake specific fuel consumption vs. speed and brake mean effective pressure are computed first. CAE vehicle simulations are finally performed evaluating the fuel consumption over emission cycles of a vehicle equipped with this engine.
\end{abstract}

(c) 2010 Professor T. Nejat Veziroglu. Published by Elsevier Ltd. All rights reserved.

\section{Introduction}

Australia's annual green house gases emissions through to the 2009 June quarter for energy - transport amount to $89 \mathrm{MtCO}_{2}$-e [1], or about $14.5 \%$ of the total. Development of more energyefficient and environmentally friendly highway transportation technologies based on heavy and light duty truck and passenger car gas engines is a key factor for reducing fuel consumption, $\mathrm{CO}_{2}$ production and pollutants emissions within Australia, therefore improving national energy security, environment, and economy. Improving the efficiency of internal combustion engines is the most promising and cost-effective approach to increasing vehicle fuel economy in the next 10 to 20 years, or until such time still far to forecast when plug-in hybrid electric or fuel cell hybrid vehicles will dominate the market [2]. Advanced combustion engines have still great potential for achieving dramatic energy efficiency improvements, with the primary hurdles that must be overcome to realize increased use of advanced combustion engines being the higher cost of these engines requiring expensive $R \& D$ when compared to conventional engines, and compliance with particularly stringent new emission regulations with the catalytic emission control technologies much less mature than gasoline engine catalysts. In the near future, Euro 6 regulations will introduce particularly tough emission limits. Implementation of these stringent emission standards is anticipated to cause a reduction in fuel efficiency due to the exhaust emission control devices needed to meet emissions regulations for both $\mathrm{NO}_{x}$ and $\mathrm{PM}$ without introduction of advanced combustion technologies.

E-mail address: a_boretti@yahoo.com 0360-3199/\$ - see front matter (c) 2010 Professor T. Nejat Veziroglu. Published by Elsevier Ltd. All rights reserved. doi:10.1016/j.ijhydene.2010.02.136 
The hydrogen fuelled internal combustion engine is now receiving large attention because of the opportunity operating lean of stoichiometry $(\lambda>2.25)$ to achieve top brake efficiencies over $45 \%$ while permitting below EURO 6 emissions without any after treatment [3-12]. Advanced combustion engine technologies being developed by the Author for gaseous fuels, not only hydrogen but also propane and methane, include modes of low-temperature lean combustion (LTC) increasing the efficiency beyond current diesel engines and reduce engine-out emissions of nitrogen oxides $\left(\mathrm{NO}_{x}\right)$ and particulate matter (PM) to near-zero levels. In addition to these combustion regimes, reduction of heat transfer, and control of load by quantity of fuel injected and a wide range of waste heat recovery technologies are also being considered to further improve engine efficiency and reduce fuel consumption.

The jet ignition pre-chamber is central to the definition of the always lean burn direct injection jet ignition engine [13-18], aimed at increased top brake efficiencies and reduced efficiency penalty changing the load. The jet ignition device is made up of a pre-chamber, connected to the main chamber through calibrated orifices, accommodating a pre-chamber fuel injector. In the standard spark plug version, the jet ignition device also includes a spark plug that ignites a prechamber mixture slightly rich that then bulk ignites the ultra lean, stratified main chamber mixture through the multiple jets of hot reacting gases entering the cylinder. In the glow plug version, the spark plug is replaced by a glow plug to increase durability and reduce maintenance costs, improve packaging and avoid occurrence of locally fuel rich conditions reducing the formation of nitrogen oxides. In the glow plug version, an even smaller amount of fuel is injected in a even smaller pre-chamber and then auto ignites after impinging on the hot glow plug surface that keeps the temperature within the pre-chamber very high. Fuel is injected directly within the cylinder by the main chamber DI injector operating single or multiple injections to produce a lean stratified mixture. This non homogeneous mixture is mildly lean in an inner region surrounded by air and some residuals from the previous cycle. The extension of the inner region is reduced in size to achieve mean chamber average mixtures ranging from $\lambda=2.25$ to $\lambda=7$. This mixture is then ignited by jets of reacting gases that issue from the pre-chamber. Fig. 1a presents a sketch of the cylinder head layout for a sample four valve pent roof combustion chamber application of the DI-JI engine, while Fig. $1 \mathrm{~b}$ presents a picture of the jet ignition assembly in the versions with a glow plug replacing the traditional spark plug.

With reference to homogeneous DI or port fuel injection (PFI) and main chamber spark ignition, non homogeneous DI and jet ignition offer the advantage of much faster, more complete, much leaner combustion, less sensitivity to mixture state and composition, and reduced heat losses to the main chamber walls. This is because of better fuel to air ratio of the combusting mixture for same chamber averaged lean conditions, combustion in the bulk of the in cylinder gases, heat transfer cushion of air between hot reacting gases and walls, very high ignition energy, multiple simultaneous ignition sites igniting the bulk of the in cylinder gases, and large concentrations of partially oxidized combustion products initiated in the pre-chamber accelerating the oxidation

\section{a Jet ignition nozzles}

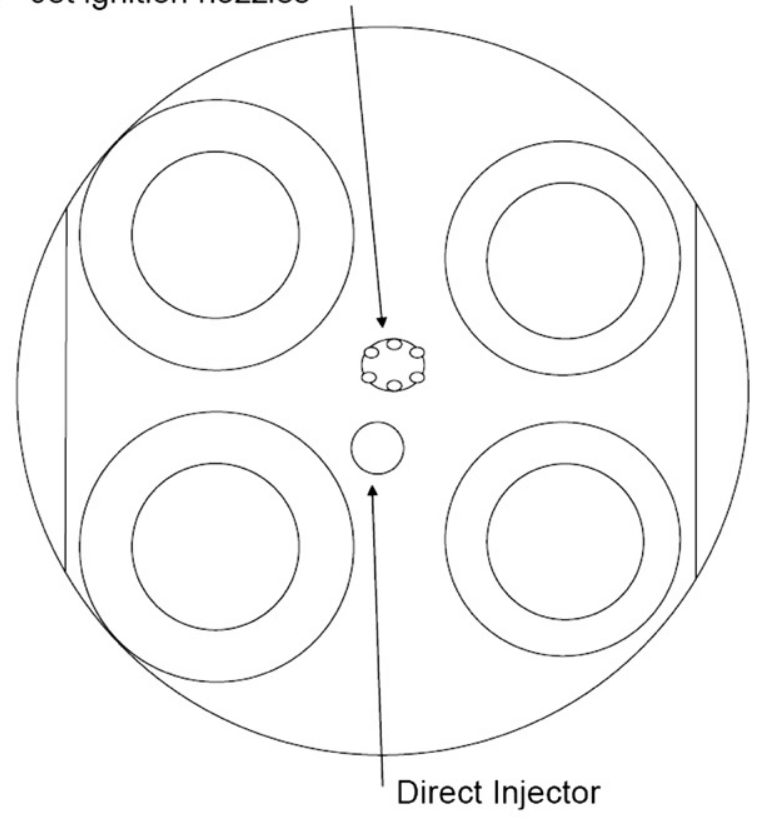

b

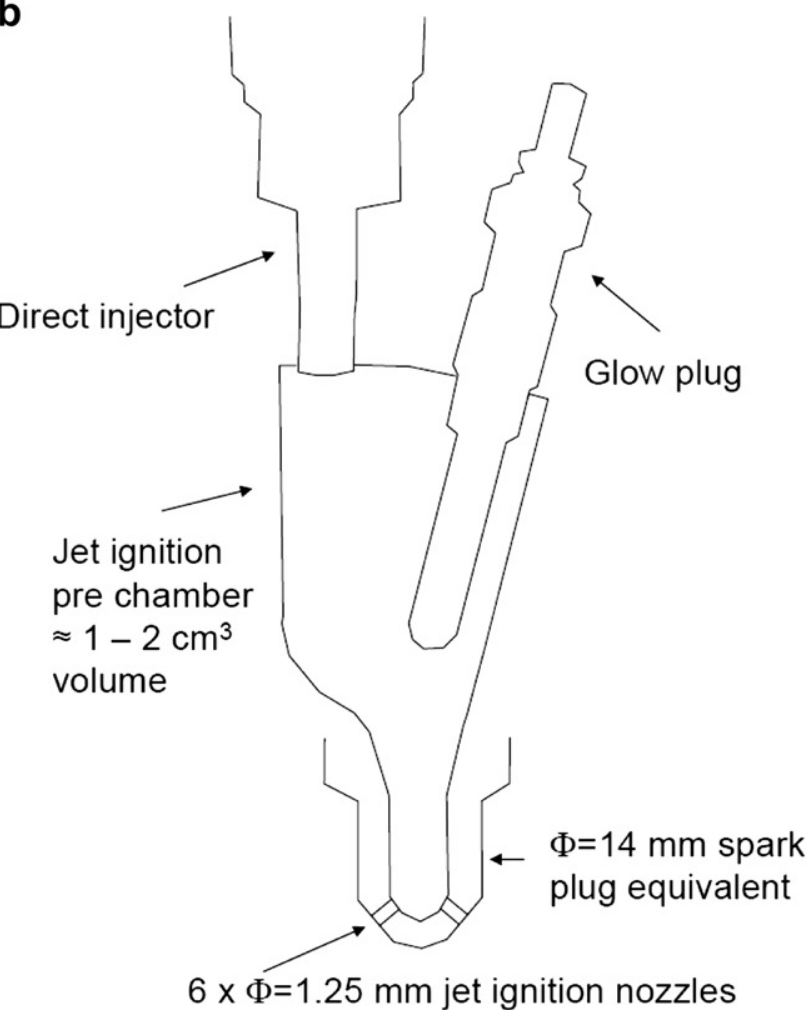

Fig. 1 - a. Cylinder head layout of the 4 valve Direct Injection Jet Ignition engine (from [16]). b. Jet ignition assembly for the 4 valve Direct Injection Jet Ignition engine in the version with a glow plug (from [16]).

of fresh reactants. The concept is an original evolution of the idea of using jet-style ignition to enable the operation of a flame-propagation engine with very lean mixtures explored many times, mostly in the large engine natural gas industry. 
The major differences of the present concept are the direct injector to the main chamber creating there mixtures from lean homogeneous to lean stratified to explore the many options of low temperature combustion, and the small size pre-chamber fitted with a second fuel injector and a spark or a glow plug, enabling start of combustion by multiple jet of hot reacting gases originating from ignition of a small fraction of the total fuel.

The volume of the jet ignition pre-chamber less than $1 \mathrm{~cm}^{3}$ is definitively small if compared with main chamber combustion chamber volumes at top dead centre of about $130 \mathrm{~cm}^{3}$ in a 11 liter in-line 6 truck engines, or about $60 \mathrm{~cm}^{3}$ in a 3.6 liter $\mathrm{V} 6$ passenger car engines, totaling respectively the 0.8 and the $1.6 \%$ (indirect injection Diesel engine combustion chambers were not less than $40-50 \%$ of the main chamber combustion chamber volumes at top dead centre). This small size volume of the pre-chamber and the requirement to inject within the pre-chamber only a very small fraction of the total fuel is supposed to keep low $\mathrm{NO}_{x}$ production otherwise a major detriment of traditional pre-chamber engines even at very lean operating conditions.

Spark plug life within the pre-chamber is generally not viewed as a major issue so long as cooling considerations are taken into account when designing the pre-chamber housing. However, the limited amount of space available to accommodate a spark plug and the therefore very far from optimal conditions may suggest replacement of a spark plug with a much smaller glow plug. Replacement of the spark plug with a glow plug not only increases durability and reduces maintenance costs, but also improves packaging and avoid occurrence of globally fuel rich conditions carefully controlling auto ignition and pre-chamber injection (The best operation of the spark ignition jet ignition pre-chamber is achieved injecting in the pre-chamber an amount of fuel slightly exceeding the stoichiometric required for the amount of air [19-25].). The operation of the glow plug pre-chamber is on the other hand more complicated, because the pre-chamber fuel injection and auto-ignition processes are strongly interrelated and some additional studies are needed to further develop the concept. While the spark plug pre-chamber has been studied for more than one decade [19-25], the glow plug pre-chamber concept is relatively new, and focus is due not only on the much more demanding direct injector, but also on the use of the glow plug to control auto ignition.

CAE engine simulations obtained on the small high-tech four cylinders, 1.5 liter, and highly turbocharged engine fuelled with propane and hydrogen [16]. This engine has displaced volume $V_{D}=\pi \cdot B^{2} / 4 \cdot S=375 \mathrm{~cm}^{3}$ ( $B$ is the bore and $S$ the stroke of the engine), pre-chamber volume $V_{P C}=1.5 \mathrm{~cm}^{3}$, true compression ratio of the engine $\rho^{*}=\left(\mathrm{V}_{\mathrm{PC}}+\mathrm{V}_{\mathrm{MCC}}+\mathrm{V}_{\mathrm{D}}\right) /$ $\left(V_{\mathrm{PC}}+\mathrm{V}_{\mathrm{MCC}}\right)=13.8\left(\mathrm{~V}_{\mathrm{MCC}}\right.$ is the main chamber combustion chamber volume at top dead centre) and reference compression ratio $\rho=\left(\mathrm{V}_{\mathrm{MCC}}+\mathrm{V}_{\mathrm{D}}\right) /\left(\mathrm{V}_{\mathrm{MCC}}\right)=14.5$. This engine shows very interesting BSFC and brake efficiency results. In the range of engine speed $3500-7500 \mathrm{rpm}$, BSFC at WOT and MBT or knock limited spark timing has a minimum of $165 \mathrm{~g} / \mathrm{kWh}$ with propane and less than $65 \mathrm{~g} / \mathrm{kWh}$ with hydrogen about $3500 \mathrm{rpm}$, corresponding to brake efficiencies of almost $48 \%$. These results clearly show the potentials to achieve even better brake efficiencies exceeding the $50 \%$ mark in the engine redesigned for lower speeds, where friction losses are lower and air-to-fuel equivalence ratios may be even leaner.

Diesel pre-chamber engines have almost disappeared after the introduction of high pressure direct fuel injection systems because of the disadvantage of an increased combustion chamber wall surface area, the resulting increased heat losses, the restriction of the combustion burn, and the increased $\mathrm{NO}_{x}$ formation for the locally richer conditions due to the injection of all the fuel within the pre-chamber. The proposed jet ignition system uses a very small pre-chamber having a very small volume compared not only to the main chamber displaced volume, but also to the main chamber combustion chamber volume, to ignite there only a very small amount of the total fuel, with the most part of the fuel being delivered directly to the main chamber. The jet ignition concept was originally developed as a replacement of standard spark plugs in port fuel injected spark ignition engines for running lean homogeneous [19-25]. The overall size of the jet ignition unit was designed such that it was possible to screw into the block using the standard spark plug hole. The volume of the jet ignition pre-chamber has been so far only 0.75 to $1.5 \mathrm{~cm}^{3}$ depending on the particular design. The operation of the direct injection jet ignition engine can not therefore be assimilated to the operation of a Diesel pre-chamber engine. Compared to normal direct injection $\mathrm{H}_{2}$ engines, the direct injection jet ignition engine has the advantage of a much faster main chamber combustion initiated in the bulk of the cylinder gases by multiple jet of hot reacting gases rather than by a spark discharge close to the cylinder head wall, with reduced heat losses because the burning fuel richer area may be an inner region not bounded by cylinder head or cylinder liner walls. Furthermore, the jet ignition permits lean main chamber air-to-fuel ratios that can not be normally achieved with a standard spark plug, with complete combustion events even in case of very small amount of fuel injected in the main chamber close to the jet ignition nozzles, and therefore throttle-less load control Diesel like. The main chamber injection process must deliver the amount of fuel needed downstream of the jet ignition nozzles. This is accomplished with fast actuating, high pressure and high flow rate injectors permitting main chamber injections to occur towards the end of the compression stroke (In the simulations presented, the end of injection is placed at top dead centre.). The bowl in piston helps with containment of the gas fuel jet stratifying the mixture close to piston wall but far from head and liner walls. The complete system therefore delivers top and part load brake efficiencies better than spark plug ignited direct injection engines at the expenses of the additional complexity of the jet ignition device.

Purpose of the paper is to explore the potential of the proposed concept before building a prototype engine and a prototype car for a final experimental product validation. The paper couples Computational fluid dynamic (CFD) and Computer Aided Engineering (CAE) engine and vehicle performance simulations to describe the operation of the hydrogen fuelled direct injection jet ignition engine standalone over the full range of speed and load and over a driving cycle installed on a vehicle. CFD simulations are used to study the mixture formation within the pre-chamber and the main chamber, the auto ignition process within the pre-chamber, 
and the subsequent jet ignition of the main chamber mixture and the combustion evolution within the main chamber. These descriptions will permit selection of direct injectors to main chamber and pre-chamber and glow plug, set-up of injection timings and flow profiles for injectors and definition of time scales of heat release processes within pre-chamber and main chamber needed in CAE simulations of engine performances. These latter simulations will finally provided engine brake mean effective pressure and specific fuel consumption over the full range of load and speed. Finally, CAE vehicle simulations will be performed by using these computed engine maps to compute the fuel economy over driving cycles of a vehicle equipped with a DI-JI hydrogen engine.

\section{Direct injector selection}

Selection of the fuel injectors is critical to the development of the DI-JI engine concept with hydrogen fuel. The fuel injector selection is already an issue in "normal" direct injection hydrogen engines. The additional constraints posed to the injection processes within the main chamber and the prechamber to fully exploit the potentials of the DI-JI engine concept with hydrogen fuel make the selection more difficult.

The amount of fuel to be introduced by the direct injector within the pre-chamber is quite small. If $\eta_{\mathrm{V}}$ is the volumetric efficiency $\eta_{\mathrm{V}}=\left(m_{\mathrm{a}}\right) /\left(\rho_{\mathrm{a}, \mathrm{i}} \cdot \mathrm{V}_{\mathrm{D}}\right)$, where $m_{\mathrm{a}}$ is the mass of air trapped within the cylinder when the intake valves close and $\rho_{\mathrm{a}, \mathrm{i}}$ is the reference air density, then the mass of fuel to be injected within the pre-chamber is roughly given by:

$m_{f, P C} \approx\left[\frac{(F / A)_{s}}{\lambda_{\mathrm{PC}}}\right] \eta_{\mathrm{V}} \rho_{a, i}(\mathrm{CR}-1) \mathrm{V}_{\mathrm{PC}}$

where $(F / A)_{s}$ is the stoichiometric fuel to air ratio, and $\lambda_{\mathrm{PC}}$ is the pre-chamber operational air to fuel equivalence ratio. As a first assumption, the mass of air within the pre-chamber at top dead centre is assumed to be equal to the total mass of air trapped within the cylinder multiplied by the ratio of prechamber volume to main chamber combustion chamber volume at top dead centre. In the detailed operation of the jet ignition pre-chamber described in [41], following the compression stroke the main chamber air (and residuals) mixture flows towards the pre-chamber through the jet ignition nozzles, with a process further complicated by the injection of fuel within the pre-chamber towards the end of the compression stroke, the following start of combustion, and the option to have back flows towards the main chamber even before the start of the expansion stroke. The actual mass of air (and residuals) within the pre-chamber at top dead centre is therefore different from this reference value, used to provide just a first guess of the amount of fuel to be introduced within the pre-chamber. $\eta_{\mathrm{V}}$ is about unity for naturally aspirated engines, but can reach values up to 2 in highly turbocharged versions with charge cooler, while $\rho$ may range from 10:1 to 15:1 depending on the boost provided by the turbo charger, and $(F / A)_{s}$ is 0.0294 for $\mathrm{H}_{2}$.

In the spark plug version, all the pre-chamber fuel has to be introduced before the spark discharge starts combustion, $\lambda_{\mathrm{PC}}$ is representative of the fuel-to-air ratio at the start of combustion, and values slightly smaller than unity (i.e. slightly fuel rich) provide the best results. In the glow plug version, auto ignition starts before all the fuel is injected, and $\lambda_{\mathrm{PC}}$ is now just representative of the total fuel that will be injected within the pre-chamber. This parameter may reach values $\lambda_{\mathrm{PC}}=2$ to 3 . Therefore, the pre-chamber DI injector has to introduce less fuel than the main chamber DI injector in general, and this amount is less in the glow plug vs. the spark plug version. In case of a turbo charged engine with unit displacement $375 \mathrm{~cm}^{3}$, compression ratio $14.5: 1$, volumetric efficiency 1.9, pre-chamber volume $1.5 \mathrm{~cm}^{3}$, the mass of hydrogen fuel to be introduced within the pre-chamber for stoichiometric conditions is $1.3 \mathrm{mg}$, and in case of a naturally aspirated engine with unit displacement $600 \mathrm{~cm}^{3}$, compression ratio $11: 1$, volumetric efficiency 1 , pre-chamber volume $1.5 \mathrm{~cm}^{3}$ it is $1 \mathrm{mg}$.

The auto ignition process set constraints to the injector pulse width duration and therefore to the flow rate and the opening and closing times. In the spark plug version, injection has to be completed before the spark discharge ignites the prechamber mixture, and it may start almost any time during the compression stroke and it may have almost any duration. In the glow plug version, fuel injection has to be faster with much higher flow rates to be effective. Enough fuel has to be introduced before the combustion evolution within the prechamber will increase there the pressure up to the very high values that will finally force the hot partially combusted products and radicals to move towards the main chamber. In the glow plug version, even if the quantity of fuel injected is much smaller, the flow rate has to be much larger and the opening times much shorter than in the spark-plug version. During the injection time, the nozzles are very unlikely to be choked, because the needle lift is opening and closing, with the minimum area being very likely the needle seat area over the most part of the injection process.

A proper estimation of the ignition delay is central to the development of the auto ignition glow plug pre-chamber. Published measured data obtained in shock tubes or rapid compression machines experiments [26-28] only partially help because not only composition, pressure and temperature differ, but also averaged and turbulent transport and diffusion are different. As a rough guideline, the auto ignition time is given in [28] as follows:

$\tau_{\text {ign }}=\mathrm{A}\left[\mathrm{X}_{\mathrm{H}_{2}}\right]^{\mathrm{x}} \phi^{\mathrm{y}} p^{z} \exp [\mathrm{E} / \mathrm{RT}]$

where $\tau_{\text {ign }}$ is the ignition delay time, $\mathrm{X}_{\mathrm{H} 2}$ the $\mathrm{H}_{2}$ mole fraction in the overall fuel-air mixture, $\phi$ the fuel-to-air equivalence ratio, $p$ is the pressure, $T$ the temperature, $R$ the gas constant and $E, A, x, y$, and $z$ are model constants. The constant $E$ in this equation is commonly referred to as the ignition activation energy. $A, x, y$ and $z$ are dimensionless. Values of $E, A, x, y$, and $z$ as well as better details of the derivation of kinetic time models in Arrhenius-type formulas as functions of equivalence ratio, temperature, pressure, and molar fraction of $\mathrm{H}_{2}$ are given in [28].

This equation provides auto ignition times of about $0.2 \mathrm{~ms}$ with $p=1$ bar, $\mathrm{T}=1000 \mathrm{~K}, \phi=0.5$, that are well below the time for complete opening and closure of today's fastest GDI piezo injectors that require times to achieve full opening lifts of 
about $0.04 \mathrm{~mm}$ of not less than $0.3 \mathrm{~ms}$. On the other hand, these injectors can also be operated part lift, with reduced pulse width and flow rates, having the minimum flow area the choked needle seat area.

Injectors should operate with not less than 200 bar of pressure. The hydrogen gas flows from an upstream higher stagnation pressure to a much lower downstream pressure is choked in the minimum effective area. Assuming ideal gas behavior, steady state choked flow occurs when the ratio of the absolute upstream pressure to the absolute downstream pressure is equal to or greater than $[(k+1) / 2]^{k /(k-1)}$, where $\mathrm{k}$ is the specific heat ratio of the gas. The equation for the mass flow rate per unit effective area is:

$\dot{m} *=\frac{\dot{m}}{A_{\mathrm{e}}}=\sqrt{k p_{0} \rho_{0}\left[\frac{2}{(k+1)}\right]^{(k+1) /(k-1)}}$

where $\rho_{0}$ is the upstream stagnation density, $p_{0}$ the upstream stagnation pressure and $A_{e}$ is the effective throat area (product of geometrical area and flow coefficient). For hydrogen at $2 \times 10^{7} \mathrm{~Pa}$ of pressure and $300 \mathrm{~K}$ of temperature, we may assume $\rho_{0}=14.4 \mathrm{~kg} / \mathrm{m}^{3}, \quad c_{\mathrm{v}}=20.857 \mathrm{~J} /(\mathrm{mol} \mathrm{K})$, $c_{\mathrm{p}}=29.658 \mathrm{~J} /(\mathrm{mol} \mathrm{K}), \quad k=c_{\mathrm{p}} / c_{\mathrm{v}}=1.422$ and therefore $\dot{m} *=1.17 \mathrm{E}+04 \mathrm{~kg} /\left(\mathrm{s} \mathrm{m}^{2}\right)$ or $11.7 \mathrm{~g} /\left(\mathrm{s} \mathrm{mm}^{2}\right)$, i.e. a flow rate of $4.09 \mathrm{~g} / \mathrm{s}$ with a minimum effective area of $0.35 \mathrm{~mm}^{2}$.

Equations (1)-(3) set constraints on pulse width and flow rate that suggest testing of fast actuating high pressure GDI injectors $[29,30]$ or specific hydrogen injectors [31] as the potential glow plug pre-chamber direct injector. Less demanding low pressure GDI injectors [32] may be used in the spark plug pre-chamber. The main chamber direct injector has to be a specific hydrogen injector [31].

The fast single coil Direct injector in [29] provides (with gasoline fuel) flow rates up to $40 \mathrm{~g} / \mathrm{s}$ at $200 \mathrm{bar}$, up to 3 multiple injections, hydraulic separation at multiple injection $\leq 0.2 \mathrm{~ms}$, and a hollow cone pattern with cone angles as required by the application. The double acting multi holes Direct injector in [31] has much larger areas, with equivalent flow areas of $0.7 \mathrm{~mm}^{2}$ through 16 holes, and may deliver up to $20 \mathrm{~g} / \mathrm{s}$ with methane at 200 bar, with response times within $0.1 \mathrm{~ms}$ and minimum injection duration $0.5 \mathrm{~ms}$. This latter injector has also been used with hydrogen in prototype applications [33].

\section{CFD engine simulation results}

Computations of the pre-chamber and cylinder mixture formation and combustion evolution have been performed by using CFD and CAE tools. A CFD tool is used to simulate the detailed fluid dynamic and combustion of the cylinder plus pre-chamber in $3 \mathrm{D}$, while a CAE tool is used to describe the full cyclic engine operation including in cylinder and prechamber. CFD simulations are performed by using STARCCM [34], while CAE simulations are performed by using GTPOWER [35] and WAVE [36].

STAR-CCM [34] injection and combustion simulations have been performed for a single engine cylinder of a larger 3.6 liters, naturally aspirated six cylinders, gasoline engine fuelled with hydrogen. This engine has $V_{D}=600 \mathrm{~cm}^{3}$, $\mathrm{V}_{\mathrm{PC}}=1.5 \mathrm{~cm}^{3}, \rho^{*}=10.8$ and $\rho=11.0$. Computations start at intake valve closure when initial conditions are set by using results of CAE simulations, and end at exhaust valve opening. Piston moves following the compression and expansion strokes, and the computational domain made up of the cylinder volume contract or expands accordingly, while layers are added and removed. The computational grid, made up of 300,000 polyhedral cells to keep the computational time and the internal memory requirements. Morphing is used to change the grid density to the variable in cylinder space aiming to produce computationally effective mesh elements in size and shape. Main chamber and pre-chamber injections are performed with very basic single holes injectors where up to sonic velocity is set during injector opening times. Simulations have been performed neglecting the residual gases within the cylinder and the pre-chamber at intake valve closure.

The flow is considered turbulent, compressible, reacting, multi species. Turbulence is modeled by using a ReynoldsAveraged Navier-Stokes (RANS) turbulence model; in particular 2 equations $\mathrm{K}-\varepsilon$ model with a two layer all $\mathrm{y}+$ wall treatment [34]. The $K-\varepsilon$ RANS model is preferred for simplicity, generality and reliability.

Kinetics equations are obtained by using DARS-CFD [37]. The kinetics equations of the 21 elementary step mechanism used here are presented in Table $1[37,41]$. A, $n$ and $E_{\mathrm{a}}$ are the Arrhenius rate constants:

$k=A T^{n} e^{-E_{a} / R T}$

where $T$ is the temperature and $R$ the gas constant.

Transport and diffusion equations are solved for the nine chemical species, namely for $\mathrm{O}_{2}, \mathrm{H}_{2}, \mathrm{H}_{2} \mathrm{O}, \mathrm{H}, \mathrm{O}, \mathrm{OH}, \mathrm{HO}_{2}, \mathrm{H}_{2} \mathrm{O}_{2}$. STAR-CCM solves the Partial Differential Equations (PDEs) for energy and species conservation [34]:

$$
\begin{aligned}
& \frac{\partial}{\partial t} \rho Y_{k}+\frac{\partial}{\partial x_{j}}\left(\rho u_{j} Y_{k}+F_{k, j}\right)=0 \\
& \frac{\partial}{\partial t} \rho h+\frac{\partial}{\partial x_{j}}\left(\rho u_{j} h+F_{h, j}\right)=\frac{\partial}{\partial t} p+u_{j} \frac{\partial}{\partial x_{j}} p+\tau_{i, j} \frac{\partial}{\partial x_{j}} u_{i}
\end{aligned}
$$

where $t$ is the time, $x_{j}$ are the spatial coordinates, $\rho$ is the density, $h$ is the enthalpy, $p$ is the pressure, $u_{j}$ are velocity vector components, $Y_{k}$ are the species mass fractions, $F_{k, j}$ are species diffusion vector components, $F_{h, j}$ are enthalpy diffusion vector components and $\tau_{i, j}$ are stress tensor components. DARS-CFD solves the Ordinary Differential Equations (ODEs) for chemical kinetics [37]:

$\frac{\partial}{\partial t} Y_{i}=\frac{\omega_{i}}{\rho}$

where $\omega_{i}$ is the species production rate.

When chemical kinetics is the limiting factor of the reacting system under investigation, near-perfect mixing of reactants and products is usually achieved. However, normally these mixing mechanisms have to rely on fluid motion or large-scale eddies and turbulence to provide the mixing. Local turbulence is particularly important as it promotes microscale mixing among the gas species. If the turbulence is too weak to provide fast mixing among the gas species, the micromixing process will interfere with the chemical kinetics. The previous model already implicitly addresses both situations. However, to further strengthen the kinetic-turbulence 
Table 1 - DARS Preprocessor $\mathrm{H}_{2} / \mathrm{O}_{2}$ kinetic mechanism (units are $\mathrm{cm}^{3} \mathrm{~mol} \mathrm{~s} \mathrm{cal} \mathrm{K}$ ).

Reaction

Arrhenius coefficients

\begin{tabular}{|c|c|c|c|c|}
\hline & & \\
\hline & & A & $\mathrm{n}$ & $E_{a}$ \\
\hline r1f: & $\mathrm{H}_{2}+\mathrm{O}_{2}=2 \mathrm{OH}$ & $1.700 \mathrm{E}+13$ & $0.000 \mathrm{E}+00$ & $1.999 \mathrm{E}+02$ \\
\hline r1b: & $\mathrm{H}_{2}+\mathrm{O}_{2}=2 \mathrm{OH}$ & $2.223 \mathrm{E}+10$ & $3.877 \mathrm{E}-01$ & $1.202 \mathrm{E}+02$ \\
\hline r2f: & $\mathrm{H}_{2}+\mathrm{OH}=\mathrm{H}_{2} \mathrm{O}+\mathrm{H}$ & $1.170 \mathrm{E}+09$ & $1.300 \mathrm{E}+00$ & $1.517 \mathrm{E}+01$ \\
\hline r2b: & $\mathrm{H}_{2}+\mathrm{OH}=\mathrm{H}_{2} \mathrm{O}+\mathrm{H}$ & $7.980 \mathrm{E}+10$ & $9.726 \mathrm{E}-01$ & $8.200 \mathrm{E}+01$ \\
\hline r3f: & $\mathrm{H}+\mathrm{O}_{2}=\mathrm{OH}+\mathrm{O}$ & $2.000 \mathrm{E}+14$ & $0.000 \mathrm{E}+00$ & $7.029 \mathrm{E}+01$ \\
\hline r3b: & $\mathrm{H}+\mathrm{O}_{2}=\mathrm{OH}+\mathrm{O}$ & $6.712 \mathrm{E}+11$ & $3.742 \mathrm{E}-01$ & $-1.190 \mathrm{E}+00$ \\
\hline r4f: & $\mathrm{O}+\mathrm{H}_{2}=\mathrm{OH}+\mathrm{H}$ & $1.800 \mathrm{E}+10$ & $1.000 \mathrm{E}+00$ & 3.693E +01 \\
\hline r4b: & $\mathrm{O}+\mathrm{H}_{2}=\mathrm{OH}+\mathrm{H}$ & $7.014 \mathrm{E}+09$ & $1.014 \mathrm{E}+00$ & $2.866 \mathrm{E}+01$ \\
\hline r5f: & $\mathrm{H}+\mathrm{O}_{2}+\mathrm{M}_{1}=\mathrm{HO}_{2}+\mathrm{M}_{1}$ & $2.100 \mathrm{E}+18$ & $-1.000 \mathrm{E}+00$ & $0.000 \mathrm{E}+00$ \\
\hline r5b: & $\mathrm{H}+\mathrm{O}_{2}+\mathrm{M}_{1}=\mathrm{HO}_{2}+\mathrm{M}_{1}$ & $6.276 \mathrm{E}+20$ & $-1.660 \mathrm{E}+00$ & $2.142 \mathrm{E}+02$ \\
\hline r6f: & $\mathrm{H}+2 \mathrm{O}_{2}=\mathrm{HO}_{2}+\mathrm{O}_{2}$ & $6.700 \mathrm{E}+19$ & $-1.420 \mathrm{E}+00$ & $0.000 \mathrm{E}+00$ \\
\hline r6b: & $\mathrm{H}+2 \mathrm{O}_{2}=\mathrm{HO}_{2}+\mathrm{O}_{2}$ & $2.002 E+22$ & $-2.080 \mathrm{E}+00$ & $2.142 \mathrm{E}+02$ \\
\hline r7f: & $\mathrm{H}+\mathrm{O}_{2}+\mathrm{N}_{2}=\mathrm{HO}_{2}+\mathrm{N}_{2}$ & $6.700 E+19$ & $-1.420 \mathrm{E}+00$ & $0.000 E+00$ \\
\hline r7b: & $\mathrm{H}+\mathrm{O}_{2}+\mathrm{N}_{2}=\mathrm{HO}_{2}+\mathrm{N}_{2}$ & $2.002 \mathrm{E}+22$ & $-2.080 \mathrm{E}+00$ & $2.142 \mathrm{E}+02$ \\
\hline r8f: & $\mathrm{OH}+\mathrm{HO}_{2}=\mathrm{H}_{2} \mathrm{O}+\mathrm{O}_{2}$ & $5.000 \mathrm{E}+13$ & $0.000 \mathrm{E}+00$ & $4.184 \mathrm{E}+00$ \\
\hline r8b: & $\mathrm{OH}+\mathrm{HO}_{2}=\mathrm{H}_{2} \mathrm{O}+\mathrm{O}_{2}$ & $4.033 \mathrm{E}+14$ & $7.798 \mathrm{E}-02$ & $2.972 \mathrm{E}+02$ \\
\hline r9f: & $\mathrm{H}+\mathrm{HO}_{2}={ }_{2} \mathrm{OH}$ & $2.500 \mathrm{E}+14$ & $0.000 \mathrm{E}+00$ & $7.950 \mathrm{E}+00$ \\
\hline rab: & $\mathrm{H}+\mathrm{HO}_{2}={ }_{2} \mathrm{OH}$ & $3.867 \mathrm{E}+10$ & $7.930 \mathrm{E}-01$ & $1.544 \mathrm{E}+02$ \\
\hline r10f: & $\mathrm{O}+\mathrm{HO}_{2}=\mathrm{O}_{2}+\mathrm{OH}$ & $4.800 \mathrm{E}+13$ & $0.000 \mathrm{E}+00$ & $4.184 \mathrm{E}+00$ \\
\hline r10b: & $\mathrm{O}+\mathrm{HO}_{2}=\mathrm{O}_{2}+\mathrm{OH}$ & $2.212 \mathrm{E}+12$ & $4.189 \mathrm{E}-01$ & $2.221 \mathrm{E}+02$ \\
\hline r11f: & $2 \mathrm{OH}=\mathrm{O}+\mathrm{H}_{2} \mathrm{O}$ & $6.000 \mathrm{E}+08$ & $1.300 \mathrm{E}+00$ & $0.000 \mathrm{E}+00$ \\
\hline r11b: & $2 \mathrm{OH}=\mathrm{O}+\mathrm{H}_{2} \mathrm{O}$ & $1.050 \mathrm{E}+11$ & $9.591 \mathrm{E}-01$ & $7.510 \mathrm{E}+01$ \\
\hline r12f: & $\mathrm{H}_{2}+\mathrm{M}_{2}=2 \mathrm{H}+\mathrm{M}_{2}$ & $2.230 \mathrm{E}+12$ & $5.000 \mathrm{E}-01$ & $3.874 \mathrm{E}+02$ \\
\hline r12b: & $\mathrm{H}_{2}+\mathrm{M}_{2}=2 \mathrm{H}+\mathrm{M}_{2}$ & $6.310 \mathrm{E}+10$ & $7.542 \mathrm{E}-01$ & $-5.301 \mathrm{E}+01$ \\
\hline r13f: & $\mathrm{O}_{2}+\mathrm{M}=2 \mathrm{O}+\mathrm{M}$ & $1.850 \mathrm{E}+11$ & $5.000 \mathrm{E}-01$ & $3.998 \mathrm{E}+02$ \\
\hline r13b: & $\mathrm{O}_{2}+\mathrm{M}=2 \mathrm{O}+\mathrm{M}$ & $4.508 \mathrm{E}+07$ & $1.115 \mathrm{E}+00$ & $-1.038 \mathrm{E}+02$ \\
\hline r14f: & $\mathrm{H}+\mathrm{OH}+\mathrm{M}_{3}=\mathrm{H}_{2} \mathrm{O}+\mathrm{M}_{3}$ & $7.500 E+23$ & $-2.600 \mathrm{E}+00$ & $0.000 \mathrm{E}+00$ \\
\hline r14b: & $\mathrm{H}+\mathrm{OH}+\mathrm{M}_{3}=\mathrm{H}_{2} \mathrm{O}+\mathrm{M}_{3}$ & $1.808 \mathrm{E}+27$ & $-3.182 \mathrm{E}+00$ & $5.073 \mathrm{E}+02$ \\
\hline r15f: & $\mathrm{H}+\mathrm{HO}_{2}=\mathrm{H}_{2}+\mathrm{O}_{2}$ & $2.500 \mathrm{E}+13$ & $0.000 \mathrm{E}+00$ & $2.929 \mathrm{E}+00$ \\
\hline r15b: & $\mathrm{H}+\mathrm{HO}_{2}=\mathrm{H}_{2}+\mathrm{O}_{2}$ & $2.956 \mathrm{E}+12$ & $4.053 \mathrm{E}-01$ & $2.292 \mathrm{E}+02$ \\
\hline r16f: & $2 \mathrm{HO}_{2}=\mathrm{H}_{2} \mathrm{O}_{2}+\mathrm{O}_{2}$ & $2.000 \mathrm{E}+12$ & $0.000 \mathrm{E}+00$ & $0.000 \mathrm{E}+00$ \\
\hline r16b: & $2 \mathrm{HO}_{2}=\mathrm{H}_{2} \mathrm{O}_{2}+\mathrm{O}_{2}$ & $5.131 \mathrm{E}+13$ & $-1.776 \mathrm{E}-01$ & $1.553 \mathrm{E}+02$ \\
\hline r17f: & $\mathrm{H}_{2} \mathrm{O}_{2}+\mathrm{M}=2 \mathrm{OH}+\mathrm{M}$ & $1.300 \mathrm{E}+17$ & $0.000 \mathrm{E}+00$ & $1.904 \mathrm{E}+02$ \\
\hline r17b: & $\mathrm{H}_{2} \mathrm{O}_{2}+\mathrm{M}=2 \mathrm{OH}+\mathrm{M}$ & $2.622 \mathrm{E}+09$ & $1.630 \mathrm{E}+00$ & $-3.268 \mathrm{E}+01$ \\
\hline r18f: & $\mathrm{H}_{2} \mathrm{O}_{2}+\mathrm{H}=\mathrm{HO}_{2}+\mathrm{H}_{2}$ & $1.600 \mathrm{E}+12$ & $0.000 \mathrm{E}+00$ & $1.590 \mathrm{E}+01$ \\
\hline r18b: & $\mathrm{H}_{2} \mathrm{O}_{2}+\mathrm{H}=\mathrm{HO}_{2}+\mathrm{H}_{2}$ & $7.375 \mathrm{E}+09$ & $5.829 \mathrm{E}-01$ & $8.682 \mathrm{E}+01$ \\
\hline r19f: & $\mathrm{H}_{2} \mathrm{O}_{2}+\mathrm{OH}=\mathrm{H}_{2} \mathrm{O}+\mathrm{HO}_{2}$ & $1.000 \mathrm{E}+13$ & $0.000 E+00$ & $7.531 E+00$ \\
\hline r19b: & $\mathrm{H}_{2} \mathrm{O}_{2}+\mathrm{OH}=\mathrm{H}_{2} \mathrm{O}+\mathrm{HO}_{2}$ & $3.144 \mathrm{E}+12$ & $2.556 \mathrm{E}-01$ & $1.453 \mathrm{E}+02$ \\
\hline
\end{tabular}

interactions, following [38] the Kong-Reitz model there described is used to scale the previously defined reaction rates $s_{i}$ through a function of the kinetic and mixing times $\tau_{\text {kin }}$ and $\tau_{\text {turb }}$ given as follows:

$\mathrm{s}_{i}^{\mathrm{t}}=\mathrm{s}_{\mathrm{i}}^{\mathrm{l}} \frac{\tau_{\text {kin }}}{\tau_{\text {kin }}+f \tau_{\text {turb }}}$

where

$\tau_{\text {turb }}=C \frac{K}{\varepsilon}$

with $C$ a constant, $K$ the turbulence kinetic energy and $\varepsilon$ the turbulence dissipation rate, while

$f=\frac{1-\exp (-r)}{0.632}$

$r=\frac{m_{\mathrm{H}_{2} \mathrm{O}}+m_{\mathrm{H}_{2}}}{1-m_{\mathrm{N}_{2}}}$

and $m$ mass fractions of the relevant species.

Default values are used for the all the constants involved in STAR-CCM. Initial and boundary conditions are obtained by using CAE simulations. The main chamber and the prechamber injectors are modeled as $\phi=0.9 \mathrm{~mm}$ and $\phi=0.3 \mathrm{~mm}$ diameter orifices where up to sonic velocity is set during opening period. Opening and closing dynamic is considered through a fixed opening and closing time providing a trapezoidal velocity distribution. The glow plug has a temperature of $1200 \mathrm{~K}$. The pre-chamber walls have a temperature of $600 \mathrm{~K}$, while the remaining main chamber walls have a temperature of $550 \mathrm{~K}$ with the exception of the cylinder liner having a temperature of $500 \mathrm{~K}$.

Simulations presented here have been obtained for operation at $7500 \mathrm{rpm}$. Diesel engines are well known being unable to run engine speed exceeding $4500 \mathrm{rpm}$ because of diffusion and kinetics controlled Diesel combustion. The DI-JI engine without a spark-plug has a kinetic controlled start of combustion within the pre-chamber, but then turbulence controlled main chamber combustion following the jet ignition. However, thanks to the high rates of reaction for hydrogen, the kinetic controlled glow plug assisted start of combustion within the small jet ignition pre-chamber may be 
effective also at the higher engine speeds of spark ignited engines. During operation at $7500 \mathrm{rpm}$ with the glow plug prechamber, a quite difficult test for auto ignition engines, the start of injection (SOI) for the main chamber injector is located $40^{\circ}$ crank angle before top dead centre (TDC), and end of injection (EOI) is located at $5^{\circ}$ crank angle after TDC. The SOI for the pre-chamber injector is $20^{\circ}$ crank angle before TDC, and EOI is located at $5^{\circ} \mathrm{crank}$ angle after TDC. The air-to-fuel equivalent ratio is $\lambda=2.25$ for the main chamber and about same for the pre-chamber.

Temperature fields within the cylinder at different crank angle positions about firing top dead centre are presented in Fig. $2 \mathrm{a}$ and $\mathrm{b}$. Interval between pictures is $2^{\circ}$ crank angle or $4.44 \times 10^{-5} \mathrm{~s}$. From top to bottom of Fig. $2 \mathrm{a}$, piston is approaching top dead centre, while from top to bottom of Fig. $2 b$, piston is moving far from top dead centre. The blue on the left of the scale identifies low temperature zones where the cold hydrogen fuel is injected, while the red on the right of the scale identifies areas where hot combustion products are displaced following the start of combustion.

Following injection, combustion starts almost immediately in hot spots with fuel available about the glow plug, but it takes a finite time have a considerable flamed volume within the pre-chamber, during which the fuel continues to enter within the pre-chamber. The strong flow from the main chamber following the compression stroke pushes the gases towards the top of the pre-chamber where combustion starts. When a significant quantity of fuel within the pre-chamber is combusted or being combusting, combustion quickly propagates to the rest of the pre-chamber volume. Finally, when combustion within the pre-chamber is fully initiated, the jet of partially combusted, hot products then rapidly spread combustion all over the main chamber through multiple jets, with help from the expansion stroke that contributes to the flow pre-chamber to main-chamber. Combustion within the main chamber then completes within a very short time despite of the lean composition, because almost all the fuel is located behind the jet ignition nozzles. These computations allow definitions of injection timings for the main chamber and pre-chamber injector, as well as prescription of combustion evolution within the pre-chamber and the main chamber.

For what concerns the combustion within the main chamber of major interest, it occurs shortly after firing TDC, when almost all the ignitable fuel mixture is reached by the multiple jets of hot combusting products and combustion then evolves very quickly. There is therefore no pressure build up during compression, and all the fuel energy is released during the expansion stroke within a very short time frame. The previous combustion evolution may obviously change varying the pre-chamber injector fuel flow rate and start of injection as well as the glow plug temperature, and in general all the other parameters affecting pressure, temperature, mean and turbulent velocity and composition of the prechamber mixture. In this particular case, the multiple jets of hot reacting gases enters the main chamber only about top dead centre, combustion starts within the main chamber only following the main chamber ignition, and there is therefore no pressure build-up within the main chamber during compression. The combustion duration $10-90 \%$ mass fuel burned is less than $10^{\circ}$ crank angle in the simulated operating point
$7500 \mathrm{Rpm}$, and it is expected to be even less than that reducing the engine speed, the processes being determined by both speed independent kinetic effects (temperatures not changing with mean piston speed) and speed dependent turbulence effects (turbulence fluctuations proportional to mean piston speed).

Simulations and experiments have been previously performed on port fuel injected engines with spark plug controlled jet ignition, hydrogen as the pre-chamber fuel and hydrogen, methane, propane and gasoline as the main chamber fuel [19-25]. These results are generally in good agreement showing a much faster rate of combustion with jet ignition. The proposed CFD simulation results are in line with what was previously measured and computed.

\section{CAE engine and vehicle simulation results}

CAE engine performance simulations have been finally performed by using the WAVE software [36]. These simulations may provide a first estimation of performance of an engine fitted with the DI-JI technology. CAE results are presented for a production HSDI Diesel engine converted to hydrogen and fitted with a DI-JI system for main chamber injection and ignition.

The engine is 2 liters, in-line four, 16 valves, fixed geometry turbo charged, with inter cooler and cooled Exhaust Gas Recirculation (EGR), full load boost of 1.5 to 2.6, bore $B=85 \mathrm{~mm}$, stroke $S=88 \mathrm{~mm}$, displaced volume per cylinder $\mathrm{V}_{\mathrm{D}}=500 \mathrm{~cm}^{3}$, compression ratio $\rho=19.5$, and operates full load with $\lambda=1.55$. The converted hydrogen engine also has the piston redesigned for a compression ratio $\rho=14$ and containment of the hydrogen jet. All the other engine parameters are unchanged. The configuration optimal for a Diesel in terms of diameters, lifts and opening timings of valves, shapes of ports and diameters and lengths of pipes, and turbo charger selection, is certainly not optimal for a hydrogen engine fitted with the DI-JI technology, which in principle can be designed for much higher engine speeds and specific power outputs. Full load operation is also considered with $\lambda=2.25$, then load is reduced changing the amount of fuel injected. The spark advance considered for the hydrogen engine is the maximum brake torque or knock limited. Combustion duration 10-90\% mass fuel burned is set by using the results of the CFD simulations of the naturally aspirated engine previously described, while the point of $50 \%$ mass fuel burned is shifted to get maximum brake torque with normalized knock intensity computed with an empirical induction-time correlation model [39] below reference values for gasoline engines. Actual combustion rates in the smaller displaced volume, higher compression ratio, turbo charged engine are expected to be faster thus leaving space for further improvements. Results of CFD simulations provide values of combustion duration $10-90 \%$ below $10^{\circ}$ of crank angle in the worst scenario. Even significant percentage variations about these values do not affect too much engine performances. The option to use different profiles of combustion duration is therefore not explored.

The knock estimation is based on an assumed octane rating for hydrogen of 120 following [3]. The octane rating is 
a
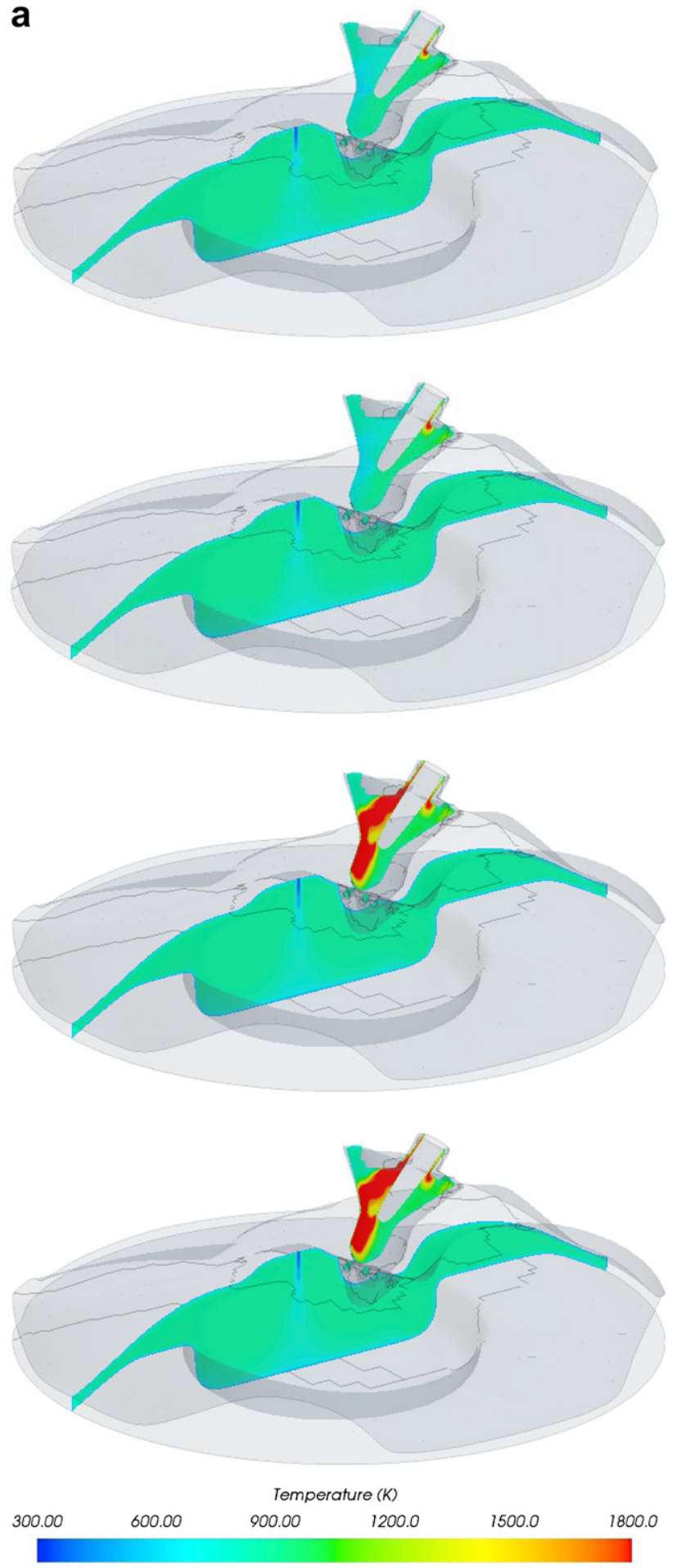

b
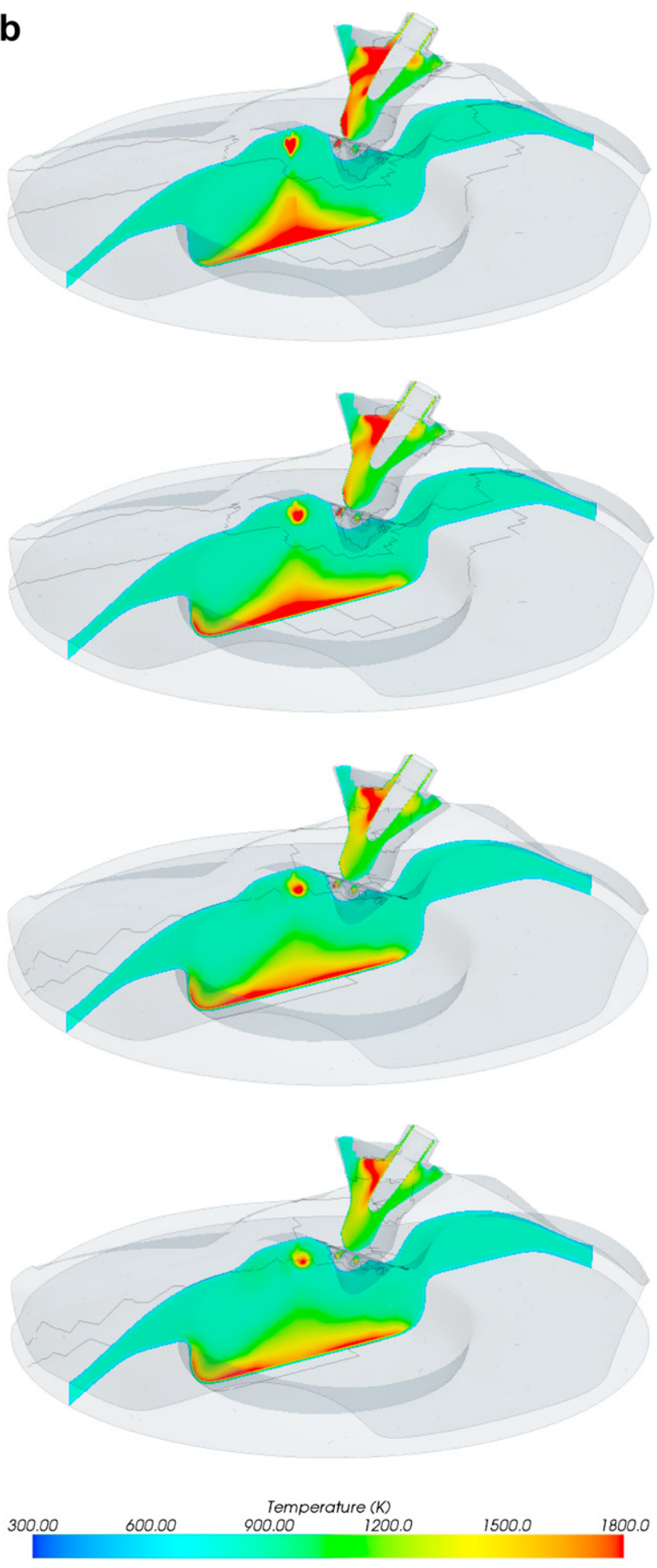

Fig. 2 - a. Computed temperature fields within the cylinder of the DI-JI hydrogen engines about TDC with intervals $2^{\circ}$ crank angle or $4.44 \times 10^{-5} \mathrm{~s}$. b. Computed temperature fields within the cylinder of the DI-JI hydrogen engines about TDC with intervals $2^{\circ}$ crank angle or $4.44 \times 10^{-5} \mathrm{~s}$.

a measure of the resistance of petrol and other fuels to autoignition in spark-ignition internal combustion engines. It is well known that hydrogen does not fit well into the normal definitions of octane number, having a very high Research Octane Number (RON) but a low Motor Octane Number (MON), or, if preferred, high resistance to knock and low resistance to pre-ignition. Knock is defined as auto-ignition of the hydrogen-air end-gas ahead of the flame front that has originated from the igniting jets. The high auto ignition temperature, the finite ignition delay and the high flame velocity of hydrogen 
means that knock, as defined above, is less likely for hydrogen relative to gasoline, and this the effect described by the induction time correlation. The global effect of both knock and pre-ignition is nearly indistinguishable, and this is the primary reason for the lack of a clear distinction between the two phenomena in hydrogen engines. The distinction is made on the basis of the controlling phenomena. Pre-ignition can be avoided through proper engine design, while knock is an inherent limit on the maximum compression ratio. Knock can be controlled by retarding the spark timing in general, and the fuel injection in the jet ignition pre-chamber in the particular case, while pre-ignition cannot be controlled by adjusting spark timing or fuel injection in the jet ignition pre-chamber. The previous results have therefore validity in the assessment of the maximum compression ratio of the hydrogen engine as well as the knock limited start of pre-chamber injection.

Fig. 3a presents the brake efficiency and the brake torque of the hydrogen and Diesel engines full load. The DI-JI hydrogen engine has better than Diesel efficiency, and despite of the lower fuel-to-air equivalence ratio, it also provides better torque. These pictures demonstrate the opportunity to produce a car fun-to-drive powered by a lean combustion hydrogen engine. Load has then been changed by changing the quantity of fuel injected for the hydrogen engine. Fig. $3 b$ presents the brake efficiency for operation with air-to-fuel equivalence ratio $\lambda=2.25,4.5$ and 6.75 or brake mean effective pressure $\mathrm{BMEP}=2,4$ and 6 bar, and brake mean effective pressure for variable air-to-fuel equivalence ratio, $\lambda=2.25,4.5$ and 6.75. High efficiencies are obtained over the most part of engine loads, demonstrating the opportunity for a car equipped with the DI-JI engine to be also fuel efficient.

A modified form of the Chen-Flynn correlation is used to model friction [36]. The correlation has a constant term (for accessory friction), a term which varies with peak cylinder pressure, a third term linearly dependent on mean piston velocity (for hydrodynamic friction) and a fourth term quadratic with mean piston velocity (for windage losses). The same four constants are used for the $\mathrm{H}_{2}$ and Diesel engines, with small differences in friction mean effective pressure that may therefore arise from different peak pressures. While the Diesel engine is calibrated to meet stringent $\mathrm{NO}_{x}$ and particulate emission limits, the only pollutant relevant to the $\mathrm{H}_{2}$ engine are the nitrogen oxides. The selected ignition timings and the operation with air-to-fuel equivalence ratios $\lambda=2.25$ and above produces low combustion temperatures and therefore negligible production of nitrogen oxides.

The original Woschni correlation is used to model heat transfer [36]. The Woschni model views the charge as having a uniform heat flow coefficient and velocity on all surfaces of the cylinder, and calculates the amount of heat transferred to and from the charge based on these assumptions. It is the most commonly used heat transfer model and can be applied to all cylinder elements. It uses multipliers to tune the model to the particular geometry, plus prescribed averaged wall temperatures and a swirl ratio. This model has been selected for the simplicity and the small amount of data needed to tune.

The Diesel CAE simulations are validated simulations with the pertinent fuel injection and combustion models [36]. The $\mathrm{H}_{2}$ CAE simulations follow modeled replacement of the fuel injection system, modifications to the piston and the addition of the jet ignition device, and introduction of combustion rates derived from previous CFD simulations in a Wiebe function. These results have therefore been only indirectly validated, and full engine experiments would certainly provide a better estimation.

The drop of brake efficiency running higher engine speeds reflects the design of the engine flow passages and valve lift profiles and the selection of the turbo-charger to maximize the low speed brake efficiencies of the Diesel (the engine operates mainly at low speeds and brake mean effective pressure during driving cycles). While the Diesel engine operating with $\lambda=1.55$ has a mass flow of air through the compressor of $265 \mathrm{~kg} / \mathrm{h}$ at $3000 \mathrm{rpm}$, at same speed the hydrogen engine operating with $\lambda=2.25$ has a mass flow of air through the compressor of $430 \mathrm{~kg} / \mathrm{h}$.

First European test cycle with extra urban driving cycle (NEDC) simulations have then been finally performed for a large passenger car sedan with the Lotus Vehicle Simulation software [40]. The car has weight $1810 \mathrm{~kg}$, frontal area $2.250 \mathrm{~m}^{2}$, drag coefficient 0.298 , rolling tyre radius $0.3160 \mathrm{~m}, 5$-speed automatic transmission with transmissions ratios 3.22/2.29/1.55/1.00/0.75, final drive ratio 2.730 . The 4 liter, in-line six cylinder, throttle body controlled, naturally aspirated gasoline engine with maximum power $190 \mathrm{~kW}$ and maximum torque $380 \mathrm{Nm}$ is replaced by the 2 liters, turbocharged, DI-JI hydrogen engine described above, having $140 \mathrm{~kW}$ maximum power and $245 \mathrm{~N} \mathrm{~m}$ maximum torque. Vehicle, tyres, driveline and gearbox data are kept constant, with the only exception of the final drive ratio reduced to 2.4. Fig. 4 presents the brake specific fuel consumption map $(\mathrm{g} / \mathrm{kWh})$ used in vehicle simulations.

The brake efficiency map of the $\lambda=2.252$ litres Turbocharged H2 DIJI compares favorably with the brake efficiency map of the $\lambda=1.552$ litres Turbocharged Diesel DI engine. This latter engine is already much better for vehicle fuel economy than the $\lambda=14$ litres naturally aspirated and throttle controlled gasoline engine, that however is still representative of power trains covering large market shares. The displacement effect shifts up by a factor of 2 the operating BMEP. The naturally aspirated gasoline engine works the most of the time at 1.5 bar BMEP and $1500 \mathrm{rpm}$, while the turbocharged engine works the most of the time at 3 bar BMEP and $1500 \mathrm{rpm}$. The gasoline engine uses $936 \mathrm{~g}$ of a fuel having $\mathrm{LHV}=43.2 \mathrm{MJ} / \mathrm{kg}$ to cover over the $1180 \mathrm{~s}$ total cycle time the $11.028 \mathrm{~km}$ distance travelled of the NEDC, for a fuel consumption of $8.487 \mathrm{~kg}$ or $366.7 \mathrm{MJ}$ of fuel energy per $100 \mathrm{~km}$. Even if the transmission is not optimized for the new engine, this latter engine only uses $213 \mathrm{~g}$ of a fuel having $\mathrm{LHV}=119.95 \mathrm{MJ} / \mathrm{kg}$, for a fuel consumption of $1.931 \mathrm{~kg}$ or 231.7 MJ of fuel energy per $100 \mathrm{~km}$.

In terms of fuel energy, the DI-JI hydrogen engine therefore uses almost $40 \%$ less fuel energy than one large naturally aspirated low tech gasoline engine. This is due to the higher BMEP permitted by downsizing (2 times larger operating BMEP following the displacement ratio), the larger top and part load brake efficiencies permitted by the DI-JI concept, the higher compression ratio, the high boost from turbo charging partially recovering the exhaust waste heat, the spark advances closer to maximum brake torque because of the better resistance to knock of hydrogen than gasoline, the removal of the throttle. 

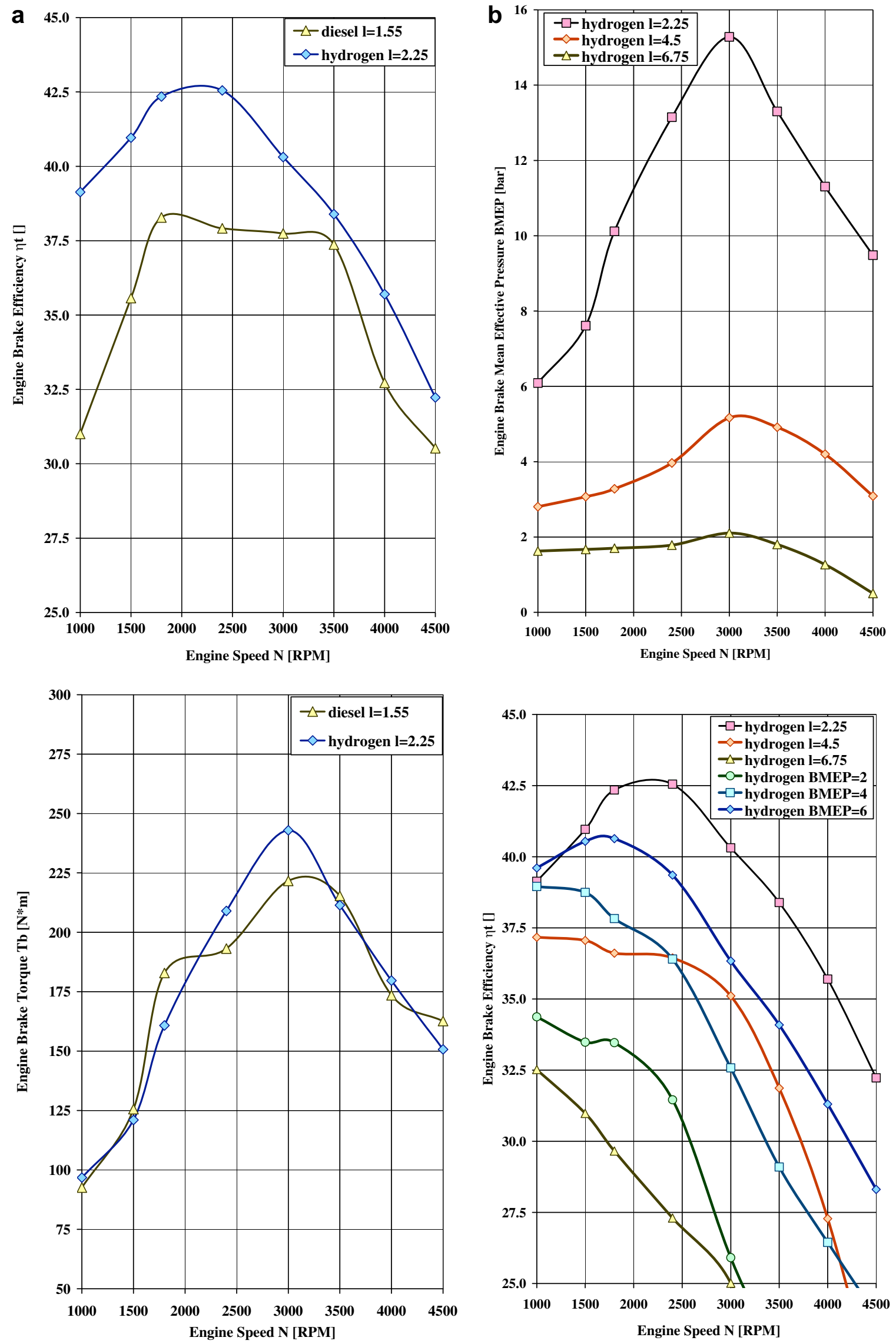

Fig. 3 - a. Computed full load brake efficiency and torque for the HSDI Diesel and the DI-JI hydrogen engines. b. Computed brake mean effective pressure and efficiency for the DI-JI hydrogen engines changing the load.

Please cite this article in press as: Boretti Alberto A., Vehicle driving cycle performance of the spark-less di-ji hydrogen engine, International Journal of Hydrogen Energy (2010), doi:10.1016/j.ijhydene.2010.02.136 


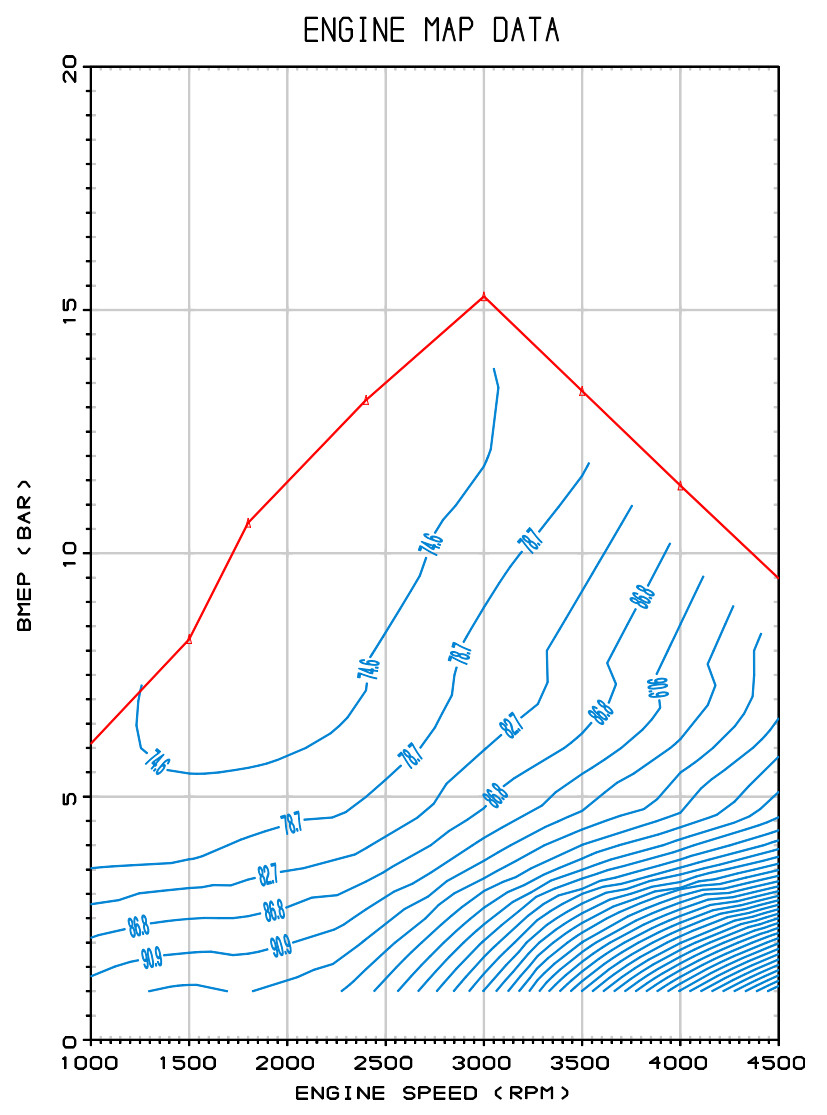

Fig. 4 - Brake specific fuel consumption map (g/kWh) used in vehicle simulations.

\section{Conclusions}

Jet ignition pre-chambers are enablers of very fast ignition and combustion of main chamber mixtures. Their evolution is central to the development of the always lean burn direct injection jet ignition engine aimed at increased top brake efficiencies and reduced penalties changing the load. A first detailed description of the operation of a spark-less jet ignition pre-chamber has been provided in the paper.

The complex operation of the pre-chamber and the cylinder, including mixture formation, auto ignition, prechamber combustion evolution, jet ignition of the main chamber mixture and main chamber combustion evolution has been described using detailed chemistry libraries coupled to turbulent flow computations. Use of the STAR-CCM CFD code coupled with the DARS chemical package has proved to be fast and reliable permitting user to focus on the application rather that in the details of chemistry or turbulence. The combustion evolution within the main chamber is then much faster than with spark plug ignition, with combustion angles $10 \%-90 \%$ of about $10^{\circ}$ running $7500 \mathrm{rpm}$ with air-to-fuel equivalence ratios of 2.25 .

CFD simulations integrated with CAE engine performance simulations have provided guidelines for selection of prechamber and main chamber fuel injectors and glow plug. Assembly of a prototype always lean burn direct injection jet ignition engine running hydrogen fuel appears to be possible by using off-the-shelf components for glow plug and direct injectors, even if some changes are needed especially in the tip area of the injectors to better exploit the advantages of the concept.

CAE engine performance simulations properly set up with the help of CFD have provided engine maps over the full range of speed and load for a 2 liters HSDI Diesel engine modified to fit the DI-JI fuel injection and ignition system and run hydrogen fuel. These maps show the DI-JI always lean burn hydrogen engine has better than Diesel full load efficiency and torque, and a reduced efficiency penalty reducing the load.

The DI-JI hydrogen engine has top brake efficiencies of $43 \%$ running $\lambda=2.25$, while the Diesel engine has a top brake efficiency of $38 \%$ running $\lambda=1.55$. The DI-JI hydrogen engine also has better torque outputs, respectively $243 \mathrm{~N} \mathrm{~m}$ vs. the $222 \mathrm{~N} \mathrm{~m}$ of the Diesel engine, and about same power output, respectively 77.5 and $78.9 \mathrm{~kW}$. The DI-JI hydrogen engine also exhibits a small penalty in efficiency reducing the load from full to a few bars of BMEP, with brake efficiencies still approaching $35 \%$ at 2 bar BMEP.

A passenger car fitted with the DI-JI hydrogen engine could therefore be fun to drive delivering good performances being at the same time fuel efficient. A large sedan with the 2 liters DI-JI hydrogen engine replacing a large naturally aspirated throttle-controlled stoichiometric gasoline engine could have a $40 \%$ improvement in fuel efficiency over the NEDC (MJ of fuel energy to complete the test).

The ability for H2ICEs to operate with near-zero engine-out emissions is primarily owed to the coupled effect of two characteristics unique to hydrogen [3]. First, nitrogen oxides are the only undesirable engine out emissions, formed by the thermal dissociation and oxidation of $\mathrm{N}_{2}$ in air during combustion. Second, the low flammability limit of hydrogen allows stable combustion at highly dilute conditions. The DI-JI concept further enhances the always lean burn operation for stable and complete combustions even at very low fuel-to-air ratios. During the ultra-lean operation, combustion temperatures are low enough such that $\mathrm{NO}_{x}$ formation rates are too slow and engine-out emissions are near zero, but the combustion process always completes.

The proposed combustion concept is fuel-neutral and may be (and has been) applied to other gaseous fuels like propane and methane. This novel technology, does not have in general major drawbacks, if not the necessity to develop up to industrial standards jet ignition devices built so far as prototypes. For the particular application to hydrogen, compliance with specific fuel properties of main chamber and prechamber injectors also require further development of injectors for faster actuation and higher flow rates and injection pressures.

Even if the Hydrogen Assisted Jet Ignition (HAJI) concept from which the DI-JI concept originates has been previously validated with some experiments, validation with experiments of the DI-JI concept is desirable.

This work still in progress is aimed at reducing and capturing emissions in transport and energy generation. Benefits of the technology includes reduced greenhouse and other emissions and reduced consumption as well as encourage the increased uptake of alternative fuels, thus potentially enhancing national energy security and reducing greenhouse gas emissions. 


\section{Acknowledgements}

Authors wish to thank Tom Morel, of Gamma Technologies Inc. (GTI) and Peter Ewing of VETA Pty Ltd and CD-adapco Australia for the support provided.

\section{R E F E R E N C E S}

[1] Australian Government Department of Climate Change. Australia's National Greenhouse Gas Inventory: update quarterly estimates of Australia's National Inventory: March Quarter 2009. http://www.climatechange.gov.au/en/climatechange/ /media/publications/greenhouse-acctg/nationalgreenhouse-accounts-june-2009.ashx [retrieved 25.1.10].

[2] US Department of energy. Energy efficiency and renewable energy, vehicle technology program, "FY 2008 Progress report For Advanced combustion engine technologies". http://www1.eere.energy.gov/vehiclesandfuels/pdfs/ program/2008_adv_combustion_engine.pdf [retrieved 25.1.10].

[3] White CM, Steeper RR, Lutz AE. The hydrogen-fueled internal combustion engine: a technical review. International Journal of Hydrogen Energy August 2006;31(10):1292-305.

[4] Knop Vincent, Benkenida Adlène, Jay Stéphane, Colin Olivier. Modelling of combustion and nitrogen oxide formation in hydrogen-fuelled internal combustion engines within a 3D CFD code. International Journal of Hydrogen Energy October 2008;33(19):5083-9.

[5] Verhelst S, Maesschalck P, Rombaut N, Sierens R. Increasing the power output of hydrogen internal combustion engines by means of supercharging and exhaust gas recirculation. International Journal of Hydrogen Energy May 2009;34(10): 4406-12.

[6] Mohammadi Ali, Shioji Masahiro, Nakai Yasuyuki, Ishikura Wataru, Tabo Eizo. Performance and combustion characteristics of a direct injection SI hydrogen engine. International Journal of Hydrogen Energy February 2007;32 (2):296-304.

[7] Boretti Alberto A, Watson Harry C. Enhanced combustion by jet ignition in a turbocharged cryogenic port fuel injected hydrogen engine. International Journal of Hydrogen Energy March 2009;34(5):2511-6.

[8] Safari H, Jazayeri SA, Ebrahimi R. Potentials of NOX emission reduction methods in SI hydrogen engines: simulation study. International Journal of Hydrogen Energy January 2009;34(2): 1015-25.

[9] D’Errico Gianluca, Onorati Angelo, Ellgas Simon. 1D thermofluid dynamic modelling of an S.I. single-cylinder $\mathrm{H} 2$ engine with cryogenic port injection. International Journal of Hydrogen Energy October 2008;33(20):5829-41.

[10] Kawahara Nobuyuki, Tomita Eiji. Visualization of autoignition and pressure wave during knocking in a hydrogen spark-ignition engine. International Journal of Hydrogen Energy April 2009;34(7):3156-63.

[11] Gomes Antunes JM, Mikalsen R, Roskilly AP. An experimental study of a direct injection compression ignition hydrogen engine. International Journal of Hydrogen Energy August 2009;34(15):6516-22.

[12] Jonathan Nieminen, Ninochka D'Souza, Ibrahim Dincer. Comparative combustion characteristics of gasoline and hydrogen fuelled ICEs. International Journal of Hydrogen Energy doi:10.1016/j.ijhydene.2009.08.098.

[13] Boretti A, Watson H. Development of a direct injection high efficiency liquid phase LPG spark ignition engine, paper presented to the SAE 2009 International Power trains, Fuels and Lubricants Meeting, Florence, Italy, June 15-17, 2009. SAE P. 2009-01-1881.

[14] Boretti A, Watson H. Development of a direct injection high flexibility CNG/LPG spark ignition engine, paper presented to the SAE 2009 International Power trains, Fuels and Lubricants Meeting, Florence, Italy, June 15-17, 2009. SAE P. 2009-01-1969.

[15] Boretti A, Watson $\mathrm{H}$. The lean burn direct-injection jetignition turbocharged liquid phase LPG engine, paper presented to the 15th Asia Pacific Automotive Engineering Conference (APAC-15), Hanoi, Vietnam, October 2009.

[16] Boretti A, Watson $\mathrm{H}$. The lean burn direct-injection jetignition gas engine. International Journal of Hydrogen Energy 2009;34:7835-7841.. doi:10.1016/j.ijhydene.2009.07.022.

[17] Boretti A, Watson $\mathrm{H}$. The lean burn direct-injection jetignition flexi gas fuel LPG/CNG engine, paper presented to the 2009 SAE Power trains, Fuels and Lubricants Meeting, San Antonio, Texas, USA, November 2009. SAE P. 2009-01-2790.

[18] Boretti A, Watson H, Tempia A. Computational analysis of the lean burn direct-injection jet-ignition hydrogen engine. Proceedings of the Institution of Mechanical Engineers, Part D: Journal of Automobile Engineering 2009;224. doi:10.1243/ 09544070jauto1278.

[19] Lumsden G, Watson HC, Glasson N, Chow C, Chalko T. Observations of hydrogen assisted jet ignition. In: Proceedings of hydrogen power thermal \& electrochemical systems international symposium, Italy, June 1995.

[20] Lumsden G, Watson HC. Optimum Control of an S.I. engine with a $\lambda=5$ capability. SAE P.950689.

[21] Lumsden G, Watson HC. HAJI operation in a hydrogen-only mode for emission control at cold start. SAE P.950412.

[22] Lawrence J. Hydrocarbon emission from a HAJI equipped ultra lean burn engine. University of Melbourne PhD Thesis, Parkville, Melbourne, Australia, 1999.

[23] Dober G. Geometric control of HC emissions. University of Melbourne PhD Thesis, Parkville, Melbourne, Australia, 2002.

[24] Hamori F. Optimising the application of HAJI to the supercharged engine. University of Melbourne PhD Thesis, Parkville, Melbourne, Australia, 2006.

[25] Mehrani P. Flame propagation and knocking in a HAJI Engine. University of Melbourne PhD Thesis, Parkville, Melbourne, Australia, 2008.

[26] Herzler J, Naumann C. Shock-tube study of the ignition of methane/ethane/hydrogen mixtures with hydrogen contents from $0 \%$ to $100 \%$ at different pressures. Proceedings of the Combustion Institute 2009;32:213-20.

[27] Gersena S, Anikina NB, Mokhova AV, Levinskya HB. Ignition properties of methane/hydrogen mixtures in a rapid compression machine. International Journal of Hydrogen Energy 2008;33:1957-64.

[28] Donato Nicole S, Petersen Eric L. Simplified correlation models for $\mathrm{CO} / \mathrm{H} 2$ chemical reaction Times. International Journal of Hydrogen Energy 2008;33:7565-79.

[29] http://delphi.com/shared/pdf/ppd/pwrtrn/gas_multec_ gdifsc.pdf (retrieved 25.1.09).

[30] http://www.conti-online.com/generator/www/de/en/ continental/automotive/general/press_service/press releases/hidden/powertrain/pr_2008_04_25_piezo_ngi_en. html (retrieved 25.1.09).

[31] http://www.hoerbiger.com/Niche-Automotive-Applications. 10762.0.html (retrieved 25.1.09).

[32] http://delphi.com/shared/pdf/ppd/pwrtrn/gas_multec_gdi_ inj.pdf (retrieved 25.1.09).

[33] Heindl R, Eichlseder H, Spuller C, Gerbig F, Heller K. New and innovative combustion systems for the H2-ICE: compression ignition and combined processes, paper presented to the 2009 SAE World Congress, Detroit, Michigan, USA, April 20-23, 2009. SAE P. 2009-01-1421. 
[34] http://www.cd-adapco.com/products/STAR-CCM_plus/ index.html (retrieved 25.1.09).

[35] http://www.gtisoft.com/applications/a_Engine_Performance. php (retrieved 25.1.09).

[36] http://www.ricardo.com/en-gb/Software/Productofferingdescription/WAVE1/ (retrieved 25.1.09).

[37] http://www.diganars.com/about.html (retrieved 25.1.09).

[38] Harry Lehtiniemi. Efficient engine CFD with detailed chemistry, ERC 2007 Symposium "Future fuels for IC engines", June 6-7, 2007, Madison, WI. http://www.erc. wisc.edu/documents/symp07-Lehtiniemi.pdf (retrieved 25.1.09).

[39] Douaud AM. Eyzatp. Four-octane-number method for predicting the anti-knock behavior of fuels and engines. SAE P. 780080.

[40] http://www.lesoft.co.uk/index1.html (retrieved 20.1.10).

[41] Boretti Alberto A. Modelling auto ignition of hydrogen in a jet ignition pre-chamber. International Journal of Hydrogen Energy; 2010;. doi:10.1016/j.ijhydene.2010.01.114. 